\title{
American eel state of buoyancy and barotrauma susceptibility associated with hydroturbine passage
}

\author{
Brett D. Pflugrath*, Ryan Harnish, Briana Rhode, Bernardo Beirao, Kristin Engbrecht, \\ John R. Stephenson and Alison H. Colotelo \\ Pacific Northwest National Laboratory, Earth Systems Science Division, 902 Battelle Blvd, Richland WA 99352, USA
}

\begin{abstract}
American eel are likely to encounter and pass through hydropower turbines, particularly during the downstream spawning migration, where exposure to stressors can potentially lead to injuries and mortality. Previous research has recovered dead eels downstream of hydropower facilities and, for some fish, injuries were easily attributed to blade strike; however, others showed no external signs of injury suggesting that other stressors, such as rapid decompression may be a potential source of mortality. For this research, yellow- and silver-phase American eel were held and allowed to acclimate to $172 \mathrm{kPa}$ (absolute pressure) in hyper/hypobaric hydro-chambers for about $1 \mathrm{~d}$. After acclimation, the state of buoyancy was determined prior to exposure to a rapid decompression simulating pressures encountered during hydroturbine passage. Fish were then examined for signs of barotrauma. Eel did not attain a state of neutral buoyancy but rather maintained negative buoyancy suggesting that eels, and possibly other benthic species, likely maintain a state of negative buoyancy to facilitate occupancy on or near the substrate. Additionally, eel were found to be resilient to rapid decompression, displaying no instantaneous mortality and minimal injuries, suggesting that barotrauma is not likely a major concern for American eel passing downstream through hydroturbines.
\end{abstract}

Keywords: downstream fish passage / rapid decompression / hydropower / swim bladder / hyperbaric / hypobaric

Résumé - État de flottabilité de l'anguille d'Amérique et sensibilité aux barotraumatismes associés au passage des hydroturbines. L'anguille d'Amérique est susceptible de rencontrer et de traverser des turbines hydroélectriques, en particulier pendant la dévalaison, où l'exposition aux facteurs de stress peut potentiellement entraîner des blessures et la mortalité. Des recherches antérieures ont permis de récupérer des anguilles mortes en aval d'installations hydroélectriques et, pour certains poissons, les blessures étaient facilement attribuables à des coups de lame; cependant, d'autres n'ont montré aucun signe externe de blessure, ce qui laisse croire que d'autres facteurs de stress, comme la décompression rapide, peuvent être une source potentielle de mortalité. Pour cette recherche, des anguilles d'Amérique en phases jaune et argentée ont été maintenues et acclimatées à $172 \mathrm{kPa}$ (pression absolue) dans des hydrochambres hyper/ hypobares pendant environ 1 jour. Après acclimatation, l'état de flottabilité a été déterminé avant l'exposition à une décompression rapide simulant des pressions rencontrées lors du passage de l'hydroturbine. Les poissons ont ensuite été examinés à la recherche de signes de barotraumatisme. L'anguille n'a pas atteint un état de flottabilité neutre, mais a plutôt maintenu une flottabilité négative, ce qui donne à penser que les anguilles, et peut-être d'autres espèces benthiques, maintiennent probablement un état de flottabilité négative pour faciliter l'occupation sur le substrat ou à proximité. De plus, on a constaté que l'anguille résistait bien à la décompression rapide, qu'elle ne présentait aucune mortalité instantanée et qu'elle n'avait subi que des blessures minimes, ce qui laisse supposer que le barotraumatisme n'est probablement pas une préoccupation majeure pour l'anguille d'Amérique qui passe en aval par des hydroturbines.

Mots-clés : passage de poissons en aval / décompression rapide / hydroelectricité / vessie natatoire / hyperbare / hypobare

\footnotetext{
*Corresponding author: brett.pflugrath@pnnl.gov
} 


\section{Introduction}

Hydropower has long been a favored choice of energy generation, accounting for $>16 \%$ of global electricity production owing to its reliability compared to other renewables and lower greenhouse gas emissions compared to nonrenewable forms of energy production (Agency, 2017). Although hydropower is a major producer of renewable and relatively inexpensive energy, its production can come at a cost to the environment, especially the aquatic ecosystem. In addition to impairments to water quality, habitat and ecosystem connectivity (Liermann et al., 2012; Ziv et al., 2012; FantinCruz et al., 2016; Buddendorf et al., 2017), hydropower facilities can cause direct injury and mortality of fishes during dam passage (Coutant and Whitney, 2000; Pracheil et al., 2016). Dam passage mortality is of particular concern for migratory fish species that must pass through hydropower facilities to complete their life cycle (Francfort et al., 1994; Haro et al., 2000b; Jager, 2006).

Exposure to rapid decompression is one of several stressors that fish passing hydropower facilities may experience, particularly when passing through turbines (Čada, 2001). The degree to which a fish is exposed, to rapid decompression, can vary dramatically (Duncan, 2011, 2013; Duncan and Carlson, 2011; Fu et al., 2016; Hou et al., 2018), but when severe, barotrauma (physical damage to body tissues caused by changes is pressures) can occur, which can potentially be fatal. Initially, the focus of hydraulic structure induced barotrauma has focused on salmonid species passing through large hydroelectric turbines (Brown et al., 2012a; b; Pflugrath et al., 2012); however, to further improve fish passage, additional species and structures are continuously being examined (Colotelo et al., 2012; Brown et al., 2013; Boys et al., 2016; Fu et al., 2016; Pflugrath et al., 2018; Boys et al., 2018; Beirão et al., 2018; Silva et al., 2018). As additional species are examined, it is clear that the methodology of assessing barotrauma, that is suitable for one group of species may not be suitable for other species, particularly the state of buoyancy prior to decompression.

The state of buoyancy prior to decompression has been determined to be a crucial variable for predicting barotrauma susceptibly for fish that are exposed to rapid decompression (Stephenson et al., 2010). Determining the state of buoyancy for fish is quite simple, if the fish is oriented head up or resting on the bottom it is negatively buoyant, head down or floating on the surface it is positively buoyant, and if the fish is horizontal in the water column then it is neutrally buoyant (Harvey, 1963; Stephenson et al., 2010; Pflugrath et al., 2012). A state of neutral buoyancy minimizes swimming efforts needed to remain at a specific level within the water column (Harvey, 1963; Sundnes and Bratland, 1972). If a fish is not neutrally buoyant, it will have to swim against either the buoyant force (positive buoyancy) or gravity (negative buoyancy), which results in the head-down or head-up orientation.

Examining barotrauma in neutrally buoyant fish is advantages, because when neutrally buoyant, the volume of the swim bladder is directly corelated to the mass of the fish and the ambient pressure (Pflugrath et al., 2012). The swim bladder is the foremost driving force of barotrauma in fish and knowing the initial state of the swim bladder prior to decompression allows for an accurate estimate of the degree to which the decompression will affect the fish (Brown et al., 2012b; Colotelo et al., 2012). This is because the gas within the swim bladder follows Boyle's Law, and has an inversely proportional relationship with the pressure. That is, if the pressure is reduced by half, the gas within the swim bladder will double in size (assuming temperature remains constant and no physiological constraints). Therefore, the ratio of the initial pressure (acclimation pressure, $\mathrm{P}_{\mathrm{A}}$ ) to the lowest pressure that a fish is exposed to (nadir pressure, $\mathrm{P}_{\mathrm{N}}$ ) is a direct representation of the factor at which the swim bladder expands during decompression. This ratio is known as the ratio of pressure change (RPC) (Stephenson et al., 2010; Brown et al., $2012 \mathrm{a}$; b). For example, a fish that is acclimated to a depth of $10 \mathrm{~m}\left(\mathrm{P}_{\mathrm{A}}=\sim 200 \mathrm{kPa}\right)$ and decompressed to $50 \mathrm{kPa}\left(\mathrm{P}_{\mathrm{N}}\right)$ will be exposed to a RPC of $4(200 / 50=4)$ and the gas within the swim bladder will quadruple in size. This method has allowed researchers to develop clear relationships between mortality or injury and RPC, allowing for the prediction of the likelihood that a fish will die or be injured when exposed to a specific decompression (Brown et al., 2012a; Pflugrath et al., 2018). However, for benthic fish, it is not likely advantageous to attain neutral buoyancy, as maintaining a state of negative buoyancy would allow a fish to rest on the substrate (Beirão et al., 2018). Therefore, the current method of using RPC to predict barotrauma may not be suitable for benthic species (Silva et al., 2018).

American eel (Anguilla rostrata) are known for their iconic spawning migrations from rivers to the Sargasso Sea and is likely to encounter hydropower plants during these migrations, which may cause injury or mortality via turbine entrainment. Prior to these migrations, yellow-phase eel live in rivers and reservoirs where they can also potentially be entrained. American eel was listed as "Endangered" by Ontario's (Canada) Endangered Species Act in 2008, "Threatened" by the Committee on the Status of Endangered Wildlife in Canada (Tremblay, 2012), and is under current reviews for inclusion in multiple other conservation lists. In North America, the species has become a particular concern for resource and hydropower managers. During their downstream migration, American eel may encounter hydroelectric dams and turbine passage has been identified as one of the potential factors contributing to population declines over the past several decades (Haro et al., 2000b).

Relatively few field studies have been conducted to quantify the occurrence of turbine passage and associated mortality of American eel during their downstream passage through hydroelectric dams. However, past studies indicate that a large proportion of silver-phase American eel may pass through turbines with high, but variable, mortality. (Haro et al., 2000a; Carr and Whoriskey, 2008; Brown et al., 2009; Eyler et al., 2016). Similar to field studies on American eel, evaluations of European eel (Anguilla anguilla) have reported a large proportion of eel passing through turbines with high, but variable, mortality. (Jansen et al., 2007; Calles et al., 2010).

Few field studies have documented the mechanism of dam passage mortality for silver-phase eels. However, evidence of blade strike mortality is easily observed and has been reported on several occasions. For example, wild short-finned eel (Anguilla australis) were captured in a fyke net downstream of a hydroelectric dam on the Patea River in New Zealand 
(Watene and Boubée, 2005). Of the eight dead eel recovered, three were cut in half, indicating they passed through the turbines, and one other showed signs of external injury; however, the other four dead eel showed no signs of external damage. It is possible that these fish died from internal injuries caused by rapid decompression during turbine passage.

Silver-phase eel are more likely to be entrained into turbines than yellow-phase eel, because of migratory behavior. However, yellow-phase eel may still encounter turbines. A portion of yellow-phase American eel populations have been observed to complete extensive upstream and downstream movements, and were classified as vagrant (Béguer-Pon et al., 2015). Additionally, transformation from yellow- to silverphase can occur either during or before the downstream spawning migration (Vladykov, 1971; Wenner and Musick, 1974; Winn et al., 1975; Hammond et al., 2003). Since both phases may encounter hydroturbines and American eel undergo significant physiological changes during the transition from yellow- to silver-phase, both phases were included as part of the present research to determine if these physiological changes can effect barotrauma susceptibility. For the present study, we evaluated buoyancy response of American eel when held at simulated depth and assessed barotrauma susceptibility in both yellow- and silver-phase American eel by exposure to simulated turbine passage pressures.

\section{Methods}

\subsection{Fish acquisition}

Both yellow- and silver-phase American eel were purchased from South Shore Trading Co. Ltd (Port Elgin, NB, Canada), a distributor and exporter of freshwater eel which purchase eels from fisherman in the New Brunswick (Canada) and Maine (USA) region. Eel were shipped from South Shore Trading Co. to Pacific Northwest National Laboratory's (PNNL) Aquatics Research Lab (ARL). Yellowphase eel were acquired in the spring of 2016 and silver-phase eel in the fall of 2017.

The median length of yellow-phase eel was $306 \mathrm{~mm}$ (range $230-423 \mathrm{~mm}$ ) with a median mass of $44.4 \mathrm{~g}$ (range 16.9 $116.1 \mathrm{~g}$ ) and the silver-phase eel had a median length of $426 \mathrm{~mm}$ (range: 216-686 mm) and median mass of $162 \mathrm{~g}$ (range: $14-507 \mathrm{~g}$ ). A total of 105 yellow-phase and 108 silverphase eel were used for buoyancy assessment and rapid decompression experiments from June 3, 2016 through August 2, 2016, and from November 17, 2017 through January 7, 2018, respectively.

Fish were held in $\sim 1000 \mathrm{~L}$ circular tanks at the PNNL ARL and provided with circulating aerated water from the Columbia River (yellow-phase eel: range $17.1-21.7^{\circ} \mathrm{C}$; silver phase eel: range $5.1-12.6^{\circ} \mathrm{C}$ ). Water quality, including total dissolved gas (TDG), dissolved oxygen (DO), and temperature, was maintained at consistent levels throughout the duration of the study periods. Generally, TDG levels were $\leq 100 \%$ and DO levels were $\geq 90 \%$. During the holding period, yellowphase eel were fed with earthworms (Lumbricus terrestris) and eventually took to pellet feed (BioVita Fry, Bio-Oregon, Longview, WA) to satiation. Food was restricted 48 hours prior to testing. Silver-phase eel were withheld feed during holding.

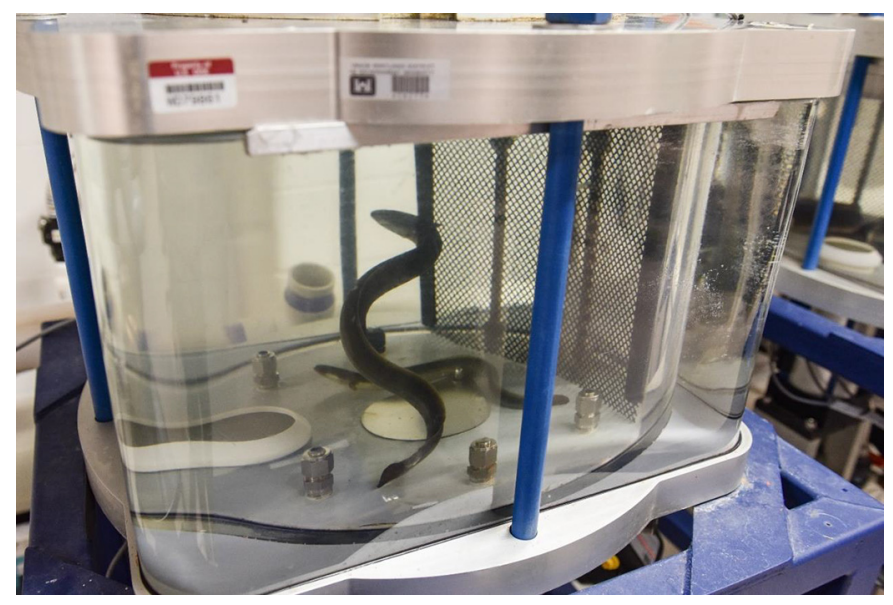

Fig. 1. Two American eel acclimating inside a hyper/hypobaric hydro-chamber.

\subsection{Buoyancy assessment}

Yellow-phase eel were netted from the general population and anesthetized by placing them in an aerated container with a concentration of tricaine methanesulfonate (MS-222, $\sim 80 \mathrm{~g} / \mathrm{L}$ ). Anesthetized fish were measured for total length and mass. Fish were allowed to recover in aerated fresh water until they regained equilibrium. To minimize handling with silver-phase eel, fish were netted from the general population and directly loaded into hyper/hypobaric hydro-chambers; measuring was conducted prior to necropsy. The computer controlled hyper/hypobaric hydro-chambers follow preprogramed pressure profiles to simulate the pressure fish experience when passing through hydroturbines (described by Stephenson et al., 2010). Two fish were loaded into a single chamber and pressurized to $172 \mathrm{kPa}$ (Fig. 1). The pressure of $172 \mathrm{kPa}$ was used because it is equivalent to approximately $7 \mathrm{~m}$ depth, which is the common depth of occupancy for silver-phase American eel reported in the literature (Haro et al., 2000a; McGrath et al., 2002; Geer, 2003).

Fish were allowed to acclimate to $172 \mathrm{kPa}$ for approximately $1 \mathrm{~d}$ before they were assessed for buoyancy. To determine the buoyancy, fish were visually examined using the following criteria: fish observed to be free swimming with a horizontal orientation and minimal swimming effort to maintain elevation in the water column were considered neutrally buoyant; fish exhibiting elevated swimming effort and a head-up or head-down orientation were considered negatively and positively buoyant respectively (Harvey, 1963; Stephenson et al., 2010; Pflugrath et al., 2012). Secondly, fish were slowly decompressed to determine the pressure of neutral buoyancy. Decompressing the fish reduces pressure on the swim bladder allowing it to expand which increases the buoyancy of the fish. The point at which the anterior portion of the fish (where the swim bladder is located) floated off the bottom of the chamber was determined to be the pressure at which the fish was neutrally buoyant. Pressures were not reduced below atmospheric pressure as to avoid causing the fish to expel gas from the swim bladder. Once this point was reached for both fish, the chamber was repressurized to $172 \mathrm{kPa}$. 


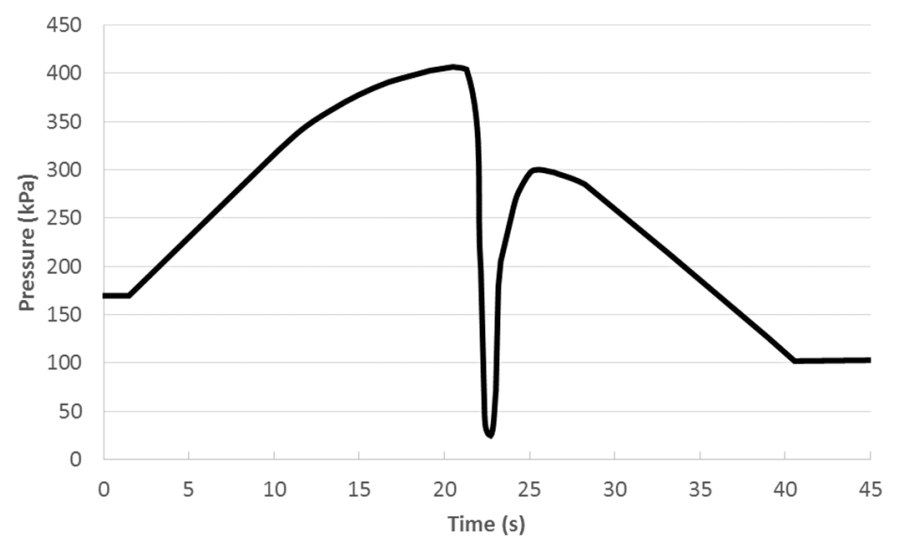

Fig. 2. Example of a pressure exposure simulating passage through a hydroturbine.

\subsection{Rapid decompression}

After buoyancy was assessed and pressure was restored to $172 \mathrm{kPa}$, fish were exposed to simulated turbine passage pressures (Fig. 2). Pressure profiles were developed from data obtained from a Kaplan turbine by deploying Sensor Fish, an autonomous senor package that records physical conditions that fish are likely to experience when passing through a hydro structure such as a turbine (Brown et al., 2012a; Deng et al., 2014). The nadir pressure was varied so that fish were examined across a range of RPC, which is not intended to represent a distribution from a specific turbine, but a range that encompasses pressures that might be observed through most turbines. As was observed with Sensor Fish, pressure within the chambers was gradually increased to about $400 \mathrm{kPa}$ over $20 \mathrm{~s}$ simulating entry into the penstock. A rapid decompression $(<1 \mathrm{~s})$ to subatmospheric pressures simulated pressures during passage through the turbine runner, and a pressure increase to about $300 \mathrm{kPa}$ ( $\sim \mathrm{s}$ ) before gradually returning to atmospheric pressure, simulated passage through the draft tube and exit into the tailrace. During decompression, fish were observed and recorded via video cameras (8Camera Pro Series, CCTV Security Pros, Cherry Hill, New Jersey USA), to determine if eel expelled gas from their swim bladders during decompression. A portion of fish was designated as controls, which were treated the same as exposure fish, including observations and necropsy, but were not exposed to the rapid decompression scenario.

\subsection{Barotrauma assessment}

Fish were removed from the chamber and assessed as alive or dead by presences or lack of ventilating. Fish determined to be dead or showing elevated signs of distress (non-responsive, prolonged disorientation, and swimming erratically) were immediately euthanized and necropsied. Alive fish were moved to holding tanks for up to $48 \mathrm{~h}$. Fish were monitored and if showing signs of distress, were immediately euthanized and necropsied. Following the $48 \mathrm{~h}$ post-treatment holding period, all remaining fish were euthanized and necropsied. Necropsies included both an external and internal examination of the eel, looking for barotraumas such as emboli and hemorrhaging throughout the structures and organs of the fish (Stephenson et al., 2010; Brown et al., 2012a; Pflugrath et al., 2018).
Table 1. Pressures at which American eel were found to be neutrally buoyant after $1 \mathrm{~d}$ of acclimation to $172 \mathrm{kPa}$. Pressures were not measured below atmospheric pressures (atm), therefore the median for silver-phase eel is presented as less than or equal to atmospheric pressure.

\begin{tabular}{lll}
\hline & Yellow-phase & Silver-phase \\
\hline$n$ & 100 & 107 \\
$n \leq \mathrm{atm}$ & 24 & 67 \\
Max $(\mathrm{kPa})$ & 169.6 & 159.0 \\
Median $(\mathrm{kPa})$ & 124.5 & $\leq 101.3$ \\
\hline
\end{tabular}

\subsection{Analysis}

The neutral buoyancy pressures for both the yellow- and silver-phase American eel were analyzed using a normality test (Shapiro-Wilk; $\alpha=0.05$; SigmaPlot). The test was found to be non-normal; therefore a rank sum test (Mann-Whitney; $\alpha=0.05$; SigmaPlot) was used to determine if there were differences between the phases.

The relationship between RPC and injury or mortality was modeled using logistic regression for both yellow- and silverphase American eel. The natural log of RPC served as the predictor variable and the occurrence of injury or mortality served as the response variable.

\section{Results}

\subsection{Buoyancy}

Buoyancy was successfully determined for 100 yellowphase and 107 silver-phase American eel, all of which were negatively buoyant at $172 \mathrm{kPa}$ (Tab. 1). A majority (67 of 107; $62.6 \%$ ) of the silver-phase eel were observed to be neutrally buoyant at pressures equal to or less than atmospheric pressure (Fig. 3). Yellow-phase eel was found to be neutrally buoyant at pressures significantly (Mann-Whitney, $p=<0.001$ ) greater than silver-phase eel.

\subsection{Barotrauma}

A total of 101 and 90 yellow- and silver-phase American eel, respectively, were successfully exposed to rapid decompression. Very few injuries and no instantaneous mortalities were observed for both phases of American eel (Tab. 2). Exposures were similar for yellow- and silver-phase eel, with yellow-phase eel on average being exposed to a slightly greater decompression (Tab. 2). Neither the occurrence of injury (Logistic regression, yellow phase $p=0.964$, silver phase $p=0.659$ ) nor mortality (Logistic regression yellow phase no mortality, silver phase $p=0.963$ ) was found to be significantly correlated to RPC for either phases. Parasites were commonly found in both phases and were predominately found within the swim bladder (Tab. 2). No injuries or mortality was observed in the control fish for either phase.

\section{Discussion}

When held at elevated pressures, eel did not attain a state of neutral buoyancy. This differs greatly from Chinook salmon 


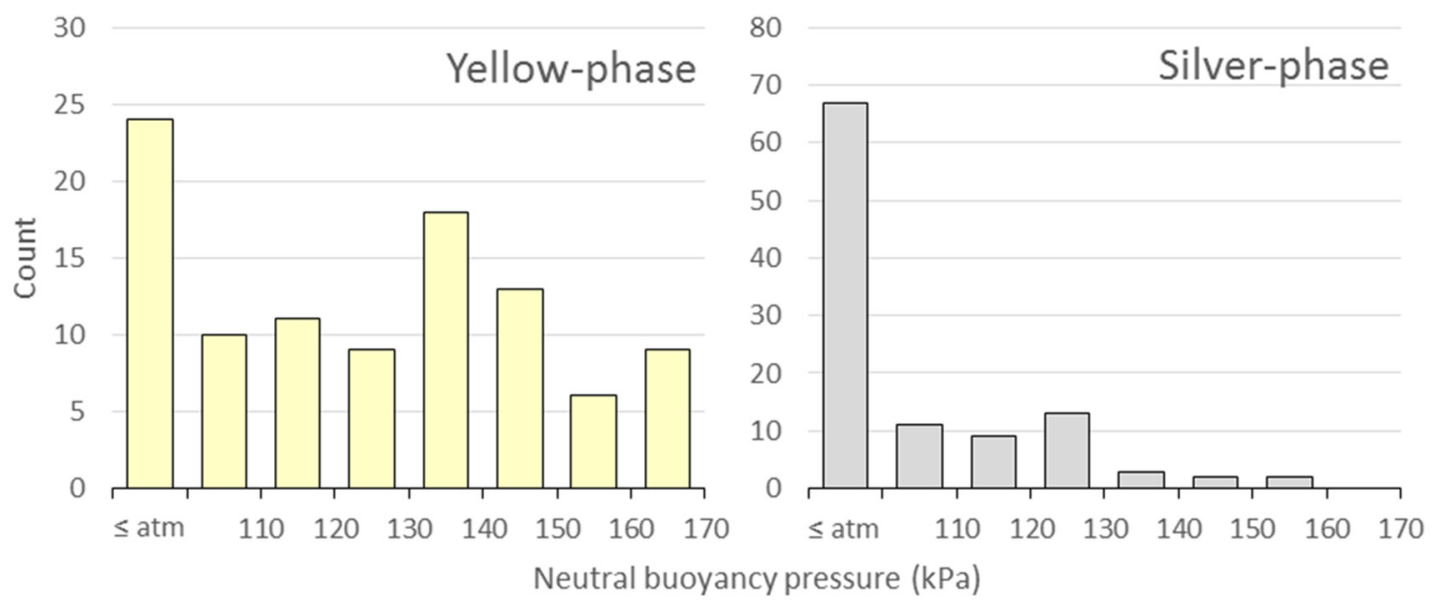

Fig. 3. Distribution of pressures that yellow- and silver-phase American eel were found to be acclimated to after $1 \mathrm{~d}$ of acclimation to $172 \mathrm{kPa}$. The first column in each chart represents the number of eel that were acclimated to pressures less than or equal to atmospheric pressures $(101.3 \mathrm{kPa})$.

(Oncorhynchus tshawytscha), of which $79 \%$ became neutrally buoyant when acclimated to $175 \mathrm{kPa}$ for $1 \mathrm{~d}$ (unpublished data from (Stephenson et al., 2010)). This supports the hypothesis that American eel may prefer a state of negative buoyancy to reduce energy expenditures while inhabiting the bottom of the water column.

Both phases of American eel were observed to have very low susceptibility to barotrauma. The silver-phase eel was exposed to a median RPC of 9.3 (10.2 for yellow-phase), which would be expected to inflict mortality rates of approximately $95 \%$ in Chinook salmon (Brown et al., 2012a). Yet, no instantaneous mortality was observed in either phase of American eel and only about ten percent of either phase was observed with injuries attributed to barotrauma. These low injury rates and no instantaneous mortality, at relatively high RPC, suggest that barotrauma at hydropower facilities is not likely a major concern for yellowand silver-phase American eel.

Yellow-phase eel were found to be neutrally buoyant at greater pressures when compared to silver-phase eel. Therefore, yellow-phase eel would have a greater amount of gas within the swim bladder on average and would therefore likely be more susceptible to barotrauma than silver-phase eel. Swim bladder ruptures were observed in yellow-phase eel and not in silverphase eel, supporting this hypothesis. However, other injuries did not follow the same trend, as a similar but slightly greater portion of silver-phase eel sustained injuries. This is contrary to previous research, which has found that swim bladder rupture is highly correlated to injury and mortality (Brown et al., 2012a), and may suggest that physiological changes that occur during transformation from yellow- to silver-phase eel, may alter barotrauma susceptibility.

Throughout the American eel life-cycle, the swim bladder undergoes various changes. The development of the eel swim bladder is linked directly to the life cycle of this catadromous fish and develops for specific purposes as the eel matures. Larval eel spends one to three years migrating from the Sargasso Sea to inland freshwater systems, and, during this time, eel develop a physostomous swim bladder, which is primarily filled and expelled via the pneumatic duct, a direct connection to the esophagus of the fish (Fänge, 1966; Pelster, 2013). Once they enter freshwater, eel transform into sexually immature yellow-phase eel (Pelster, 2013). A yellow-phase eel's metamorphosis into a silver-phase eel starts once the fish becomes sexually mature and begins its return journey to the Sargasso Sea (Pelster, 2013). It is during this time that the eel's swim bladder starts functioning similar to a physoclistous fish (Pelster, 2013), which relies on a rete (vascular bundle) to add or remove gas from the swim bladder (Fänge, 1966). The transformation of the eel swim bladder is essential during their spawning migration from freshwater to the Sargasso Sea wherein they undertake diel vertical migrations between depths of 200 and $1000 \mathrm{~m}$ (Aarestrup et al., 2009). There is currently a lack of literature to suggest when, during this transition from yellow-phase to silver-phase, the swim bladder changes, particularly if this occurs in freshwater, or once they enter saltwater.

During the present study, a majority of silver-phase eel (64 of 90) was observed expelling gas from the swim bladder during decompression, whereas, slightly less than half (45 of 101) of the yellow-phase eel exhibited this reflex. This suggests that the pneumatic duct is still functional in silverphase American eel. To attain depths of $1000 \mathrm{~m}(>10000 \mathrm{kPa})$ during the migration to the Sargasso Sea, it is not practical for an eel to fill the swim bladder by gulping air at the water surface. In order to attain a state of neutral buoyancy at a depth of $1000 \mathrm{~m}$, the eel would be required to gulp a volume of air equal to 100 times the volume needed for neutral buoyancy at atmospheric pressure. Not only is this impossible, but the eel would then have to fight a significant buoyant force in order to dive to deeper depths. Therefore, to introduce gas into the swim bladder, the eel must rely heavily, if not exclusively, on the rete. However, if the pneumatic duct still remains functional, the eel may be capable of expelling gas from the swim bladder rapidly, rather than relying on the rete which can take considerably longer (Fänge, 1983). This would aid eel in the extensive diel vertical migrations that have been observed (Aarestrup et al., 2009). Eel have a considerably more developed rete on the swim bladder than most other physostomous fish and can regulate gas within the swim 
Table 2. Number, exposure, and occurrence of mortality and injuries in yellow- and silver-phase American eel exposed to rapid decompression simulating hydroturbine passage. Percentages represent the portion of exposed fish that were recorded with the designated injury or observation.

\begin{tabular}{|c|c|c|}
\hline & Yellow-phase & Silver-phase \\
\hline \multicolumn{3}{|l|}{ Exposure } \\
\hline $\begin{array}{l}\text { Nadir }(\mathrm{kPa}) \text { median } \\
\text { (range) }\end{array}$ & $2.4(1.2-8.1)$ & $2.7(1.6-8.4)$ \\
\hline RPC median (range) & $10.2(3.1-21.4)$ & $9.3(3.0-16.1)$ \\
\hline$n$ & 105 & 108 \\
\hline Control & 4 & 18 \\
\hline Exposed & 101 & 90 \\
\hline Instantaneous mortality & 0 & 0 \\
\hline Injured & $11(10.9 \%)$ & $12(13.3 \%)$ \\
\hline \multicolumn{3}{|l|}{ Emboli } \\
\hline Heart & 0 & $1(1.1 \%)$ \\
\hline \multicolumn{3}{|l|}{ Hemorrhaging } \\
\hline Intestinal & $1(1.0 \%)$ & 0 \\
\hline Liver & 0 & $4(4.4 \%)$ \\
\hline Heart & 0 & $1(1.1 \%)$ \\
\hline Swim bladder & $3(3.0 \%)$ & $1(1.1 \%)$ \\
\hline Pectoral fin & $3(3.0 \%)$ & $1(1.1 \%)$ \\
\hline Anal fin & 0 & $3(3.3 \%)$ \\
\hline Dorsal fin & 0 & $1(1.1 \%)$ \\
\hline \multicolumn{3}{|l|}{ Hematoma } \\
\hline Liver & $1(1.0 \%)$ & $1(1.1 \%)$ \\
\hline Ruptured gall bladder & 0 & $5(5.6 \%)$ \\
\hline Intestinal volvulus & $1(1.0 \%)$ & 0 \\
\hline Burst capillaries along & $1(1.0 \%)$ & 0 \\
\hline \multicolumn{3}{|l|}{ kidney wall } \\
\hline Parasites & $52(49.5 \%)^{*}$ & $98(90.7 \%)^{*}$ \\
\hline $\begin{array}{l}\text { Expelled gas during } \\
\text { decompression }\end{array}$ & $45(45.0 \%)$ & $64(71.1 \%)$ \\
\hline
\end{tabular}

${ }^{*}$ Percentages include controls.

bladder by gas exchange at similar rates to physoclistous fish (Fänge, 1983). Because the swim bladder expansion that occurs during rapid decompression is one of the driving forces of barotrauma, the ability to quickly remove gas from the swim bladder has been proposed as an ability that may prevent barotrauma (Brown et al., 2012a; b). Swim bladder rupture was not an issue for silver-phase eel, likely due to their ability to expel gas from the swim bladder and the state of negative buoyancy prior to decompression.

Testing further acclimation pressures may reveal buoyancy capabilities of eel. During necropsy, eel did not appear to have under inflated swim bladders. This may suggest that at maximum capacity, the volume of the swim bladder may not provide sufficient buoyancy for the fish to even attain neutral buoyancy. Testing the maximum capacity of the swim bladder (Pflugrath et al., 2012) may reveal that eel are actually incapable of attaining neutral buoyancy. Additionally, during other rapid decompression studies, Chinook salmon was acclimated to three different pressures, and as the pressures increased, less and less fish attained neutral buoyancy after $1 \mathrm{~d}$ of acclimation (unpublished data from (Stephenson et al.,
2010; Brown et al., 2012a)). This was noteworthy because fish were provided a gas pocket to enable gulping gas into the swim bladder and this gas pocket was pressurized. Access to a pressurized air pocket should enable these fish to artificially fill the swim bladder with more gas than would be possible in nature and allow them to attain neutral buoyancy at any pressure within the chambers. However, at the greater acclimation pressure, which happened to be near the maximum pressure at which Chinook salmon would be capable of attaining neutral buoyancy in nature (Pflugrath et al., 2012), a significant portion of fish did not attain neutral buoyancy. If eel were held at a pressure closer to surface pressure, they may have attained neutral buoyancy. For the present study, acclimation pressures were selected based on the likelihood that eels inhabit the bottom of the water column and will enter turbine intakes from depth (Haro et al., 2000a; McGrath et al., 2002; Geer, 2003). However, there is potential, especially in cases where low-head hydropower is installed, that eels may enter turbines from shallower depths and it may be beneficial to examine additional acclimation depths.

The health of the swim bladder is likely critical for migrating eel. During the extensive spawning migrations to the Sargasso Sea (Aarestrup et al., 2009), eel require a highly functioning swim bladder and any impairment of swim bladder function significantly threatens the success of the spawning migration (Pelster, 2015). Though no instantaneous mortality was observed in the yellow-phase American eel, nine fish were observed to have injuries to the swim bladder. Additionally, parasitic nematodes (Anguillicoloides crassus) were observed in many of the swim bladders of both phases of examined fish. These nematodes cause physiological damage to the swim bladder of infected eels and impair swim bladder function (Székely et al., 2009; Pelster, 2015). European eel has been observed to have a reduced rate of gas secretion when infected, which could affect buoyancy (Würtz et al., 1996). In the present study, infected yellow-phase eel had a much lower frequency of expelling gas from their swim bladder during exposure to rapid decompression (about 55\%) compared to non-infected eel (about 88\%). In this study, it is unclear whether the presence of these parasites in the swim bladder prevented them from expelling gas through the pneumatic duct or whether infected eel had less gas in their swim bladders prior to decompression due to the presence of the nematodes. However, previous research has shown that adult eel with more than 10 adult parasites in their swim bladder have been observed to contain $60 \%$ less gas in their swim bladders compared to uninfected eel (Würtz et al., 1996). Either way, the presence of parasites in the swim bladder, which was observed in $70 \%$ of eel in this study and is suggested to be a common issue for many species of eels (Székely et al., 2009), is likely to influence the response to rapid decompression events that occur during turbine passage.

The present study and others have demonstrated that the state of the swim bladder, and therefore buoyancy of the fish, is a critical variable for predicting barotrauma. However, no field studies have been able to determine the state of buoyancy of fish in situ. Three-dimensional (3D) acoustic telemetry has been used to determine the depths of active migrating fish, but this has been limited to juvenile Chinook salmon (Li et al., 2018). 3D acoustic telemetry provides significant insight as to what depth fish may be acclimated to prior to entrainment through turbines; 
however, it doesn't determine the state of buoyancy. Further research is needed to develop methods to determine the state of buoyancy prior to turbine passage, especially in species such as eels and other benthic fish (Silva et al., 2018).

\section{Conclusion}

The present study suggests that yellow- and silver-phase American eel are not likely to attain neutral buoyancy, but rather maintain a state of negative buoyancy, possibly to aid in remaining at the bottom of the water column. Additionally, this state of negative buoyancy, and the ability to expel gas from the swim bladder, may provide a safe guard to barotrauma as these fish were found to have a high tolerance to rapid decompression. An in situ examination of the state of buoyancy is advisable to confirm that these results are not biased by any artificial variables that are inherent while conducting laboratory studies.

Acknowledgments. This study was funded by the United States Department of Energy, Energy Efficiency and Renewable Energy, Water Power Technologies Office (WPTO). The authors' views expressed in this publication do not necessarily reflect the views of WPTO or the United States government. This research was conducted in compliance with a protocol approved by Pacific Northwest National Laboratory's Institutional Animal Care and Use Committee. The Pacific Northwest National Laboratory is operated for U.S. Department of Energy by Battelle Memorial institute under contract DEAC05-76RLO 1830.

\section{References}

Aarestrup K, Økland F, Hansen MM, Righton D, Gargan P, Castonguay M, Bernatchez L, Howey P, Sparholt H, Pedersen MI. 2009. Oceanic spawning migration of the European eel (Anguilla anguilla). Science 325: 1660-1660.

Béguer-Pon M, Castonguay M, Shan S, Benchetrit J, Dodson JJ. 2015. Direct observations of American eels migrating across the continental shelf to the Sargasso Sea. Nature Commun 6: 8705 .

Beirão BV, Silva LGM, Brown RS, Walker RW. 2018. Determining barotrauma on the Amazonian catfish Pimelodus pictus experimentally exposed to simulated rapid decompression occurred in hydropower turbines. Mar Freshw Res 69: 19313-1921.

Boys CA, Robinson W, Miller B, Pflugrath B, Baumgartner LJ, Navarro A, Brown R, Deng Z. 2016. A piecewise regression approach for determining biologically relevant hydraulic thresholds for the protection of fishes at river infrastructure. J Fish Bio 88: 1677-1692.

Boys CA, Pflugrath BD, Mueller M, Pander J, Deng Z, Geist J. 2018. Phisical and hydraulic forces experienced by fish passing through three different low-head hydropower turbines. Mar Freshw Res 69: 1937-1944.

Brown L, Haro A, Castro-Santos T. 2009. Three-dimensional movement of silver-phase American eels in the forebay of a small hydroelectric facility. Am Fish Society Symp 277-291.

Brown RS, Carlson TJ, Gingerich AJ, Stephenson JR, Pflugrath BD, Welch AE, Langeslay MJ, Ahmann ML, Johnson RL, Skalski JR. 2012a. Quantifying mortal injury of juvenile Chinook salmon exposed to simulated hydro-turbine passage. Trans Am Fish Soc 141: $147-157$.
Brown RS, Pflugrath BD, Colotelo AH, Brauner CJ, Carlson TJ, Deng ZD, Seaburg AG. 2012b. Pathways of barotrauma in juvenile salmonids exposed to simulated hydroturbine passage: Boyle's law vs. Henry's law. Fish Res 121: 43-50.

Brown RS, Cook KV, Pflugrath BD, Rozeboom LL, Johnson RC, McLellan JG, Linley TJ, Gao Y, Baumgartner LJ, Dowell FE. 2013. Vulnerability of larval and juvenile white sturgeon to barotrauma: Can they handle the pressure? Conserv Physiol 1: $\cot 019$

Buddendorf WB, Malcolm IA, Geris J, Wilkinson ME, Soulsby C. 2017. Metrics to assess how longitudinal channel network connectivity and in-stream Atlantic salmon habitats are impacted by hydropower regulation. Hydrol Process 31: 2132-2142.

Čada GF. 2001. The development of advanced hydroelectric turbines to improve fish passage survival. Fisheries 26: 14-23.

Calles O, Olsson I, Comoglio C, Kemp P, Blunden L, Schmitz M, Greenberg L. 2010. Size-dependent mortality of migratory silver eels at a hydropower plant, and implications for escapement to the sea. Freshw Bio 55: 2167-2180.

Carr J, Whoriskey F. 2008. Migration of silver American eels past a hydroelectric dam and through a coastal zone. Fish Manag Ecol 15: 393-400.

Colotelo AH, Pflugrath BD, Brown RS, Brauner CJ, Mueller RP, Carlson TJ, Deng ZD, Ahmann ML, Trumbo BA. 2012. The effect of rapid and sustained decompression on barotrauma in juvenile brook lamprey and Pacific lamprey: Implications for passage at hydroelectric facilities. Fish Res 129: 17-20.

Coutant CC, Whitney RR. 2000. Fish behavior in relation to passage through hydropower turbines: A review. Trans Am Fish Soc 129: 351-380.

Deng Z, Lu J, Myjak MJ, Martinez JJ, Tian C, Morris SJ, Carlson TJ, Zhou D, Hou H. 2014. Design and implementation of a new autonomous sensor fish to support advanced hydropower development. Rev Sci Instrum 85(115001): 1-6.

Duncan JP. 2011. Characterization of fish passage conditions through a Francis turbine, spillway, and regulating outlet at Detroit Dam, Oregon, using sensor fish, 2009-2010. Richland, Washington, USA: Pacific Northwest National Laboratory, PNNL-20408.

Duncan JP. 2013.Characterization of fish passage conditions through the fish weir and turbine unit 1 at Foster Dam, Oregon, using sensor fish, 2012. Richland, Washington, USA: Pacific Northwest National Laboratory, PNNL-22236.

Duncan JP, Carlson TJ. 2011. Characterization of fish passage conditions through a Francis turbine, spillway, and regulating outlet at Detroit Dam, Oregon, using sensor fish, 2009. Richland, Washington, USA: PNNL-20365.

Eyler SM, Welsh SA, Smith DR, Rockey MM. 2016. Downstream passage and impact of turbine shutdowns on survival of silver American eels at five hydroelectric dams on the Shenandoah River. Trans Am Fish Soc 145: 964-976.

Fänge R. 1966. Physiology of the swimbladder. Physiol Rev 46: 299-322.

Fänge R. 1983. Gas exchange in fish swim bladder. Rev Physiol Biochem Pharmacol 97: 111-158.

Fantin-Cruz I, Pedrollo O, Girard P, Zeilhofer P, Hamilton SK. 2016. Changes in river water quality caused by a diversion hydropower dam bordering the Pantanal floodplain. Hydrobiologia 768: 223-238.

Francfort JE, Čada GF, Dauble DD, Hunt RT, Jone DW, Rinehart BN, Sommers GL, Costello RJ. 1994. Environmental mitigation at hydroelectric projects: Benefits and costs of fish passage and protection. United States Department of Energy, Idaho Operations Office. 
Fu T, Deng ZD, Duncan JP, Zhou D, Carlson TJ, Johnson GE, Hou H. 2016. Assessing hydraulic conditions through Francis turbines using an autonomous sensor device. Renew Energy 99: 1244-1252.

Geer PJ. 2003. Distribution, relative abundance, and habitat use of American eel Anguilla rostrata in the Virginia portion of the Chesapeake Bay. Am Fish Soc Symp 33: 101-115.

Hammond SD, Welsh SA, Bledsoe K, Dixon DA, Hartman KJ, Mazik P. 2003. Seasonal movements of yellow-phase American eels (Anguilla rostrata) in the Shenandoah River, West Virginia. Doctoral dissertation, Morgantown, West Virginia USA: West Virginia University.

Haro A, Castro-Santos T, Boubée J. 2000a. Behavior and passage of silver-phase American eels, Anguilla rostrata (LeSueur), at a small hydroelectric facility. Dana 12: 33-42.

Haro A, Richkus W, Whalen K, Hoar A, Busch W.-D, Lary S, Brush T, Dixon D. 2000b. Population decline of the American eel: Implications for research and management. Fisheries 25: 7-16.

Harvey HH. 1963. Pressure in the early life history of sockeye salmon. Doctoral dissertation, British Columbia, Canada: University of British Columbia, Vancouver.

Hou H, Deng ZD, Martinez JJ, Fu T, Duncan JP, Johnson GE, Lu J, Skalski JR, Townsend RL, Tan L. 2018. A hydropower biological evaluation toolset (HBET) for characterizing hydraulic conditions and impacts of hydro-structures on fish. Energies 11: 990.

International Energy Agency. 2017. Key world energy statistics. Paris: International Energy Agency.

Jager HI. 2006. Chutes and ladders and other games we play with rivers. I. Simulated effects of upstream passage on white sturgeon. Can J Fish Aquatic Sci 63: 165-175.

Jansen HM, Winter HV, Bruijs MC, Polman HJ. 2007. Just go with the flow? Route selection and mortality during downstream migration of silver eels in relation to river discharge. ICES J Mar Sci 64: $1437-1443$

Li X, Deng ZD, Fu T, Brown RS, Martinez JJ, McMichael GA, Trumbo BA, Ahmann ML, Renholds JF, Skalski JR. 2018. Threedimensional migration behavior of juvenile salmonids in reservoirs and near dams. Sci Rep 8: 956.

Liermann CR, Nilsson C, Robertson J, Ng RY. 2012. Implications of dam obstruction for global freshwater fish diversity. BioSci 62: 539-548.

McGrath KJ, Dembeck J, McLaren JB, Fairbanks AA, Cluett S. 2002. Surface and midwater trawling for American eels in the St. Lawrence River. Bio Manag Prot Catadromous Eels 33.

Pelster B. 2013. The Swimbladder. In: Trischitta F, Takei Y, Sébert P, eds. Eel Physiology. Florida, USA, Boca Raton: CRC Press, pp 49-72.

Pelster B. 2015. Swimbladder function and the spawning migration of the European eel Anguilla anguilla. Front Physiol 4(486): 1-10.

Pflugrath BD, Brown RS, Carlson TJ. 2012. Maximum neutral buoyancy depth of juvenile Chinook salmon: Implications for survival during hydroturbine passage. Trans Am Fish Soc 141: $520-525$.

Pflugrath BD, Boys CA, Cathers B. 2018. Predicting hydraulic structure-induced barotrauma in Australian fish species. Mar Freshw Re 69: 1954-1961.

Pracheil BM, DeRolph CR, Schramm MP, Bevelhimer MS. 2016. A fish-eye view of riverine hydropower systems: The current understanding of the biological response to turbine passage. Rev Fish Biol Fish 26: 153-167.

Silva LGM, Beirão BV, Falcão RC, de Castro ALF, Dias EW. 2018. Warning, it's a catfish! Novel approaches are needed to study the effects of rapid decompression on benthonic species. Mar Freshw Res 69: 1922-1933.

Stephenson JR, Gingerich AJ, Brown RS, Pflugrath BD, Deng Z, Carlson TJ, Langeslay MJ, Ahmann ML, Johnson RL, Seaburg AG. 2010. Assessing barotrauma in neutrally and negatively buoyant juvenile salmonids exposed to simulated hydro-turbine passage using a mobile aquatic barotrauma laboratory. Fish Res 106: 271-278.

Sundnes G, Bratland P. 1972. Notes on the gas content and neutral buoyancy in physostome fish, FiskDir Skr Ser Havunders 16: 89-97.

Székely C, Palstra A, Molnár K, Van den Thillart G. 2009. Impact of the swim-bladder parasite on the health and performance of European eels. Spawning migration of the European eel. Dordrecht, Netherlands: Springer, pp. 201-226.

Tremblay V. 2012. COSEWIC assessment and status report on the American eel Anguilla rostrata in Canada. Ottawa, Canada: COSEWIC.

Vladykov VD. 1971. Homing of the American eel, Anguilla rostrata, as evidenced by returns of transplanted tagged eels in New Brunswick. Canadian Field-Nat 85: 241-248.

Watene E, Boubée J. 2005. Selective opening of hydroelectric dam spillway gates for downstream migrant eels in New Zealand. Fish Manag Ecol 12: 69-75.

Wenner CA, Musick J. 1974. Fecundity and gonad observations of the American eel, Anguilla rostrata, migrating from Chesapeake Bay, Virginia. J Fish Board Can 31: 1387-1391.

Winn H, Richkus W, Winn L. 1975. Sexual dimorphism and natural movements of the American eel (Anguilla rostrata) in Rhode Island streams and estuaries. Helgoländer Wissenschaftliche Meeresuntersuchungen 27: 156.

Würtz J. Taraschewski H, Pelster B. 1996. Changes in gas composition in the swimbladder of the European eel (Anguilla anguilla) infected with Anguillicola crassus (Nematoda). Parasitology 112: 233-238.

Ziv G, Baran E, Nam S, Rodríguez-Iturbe I, Levin SA. 2012. Trading-off fish biodiversity, food security, and hydropower in the Mekong River Basin. Proc of the Natl Acad Sci 109: $5609-5614$.

Cite this article as: Pflugrath BD, Harnish R, Rhode B, Beirao B, Engbrecht K, Stephenson JR, Colotelo AH. 2019. American eel state of buoyancy and barotrauma susceptibility associated with hydroturbine passage. Knowl. Manag. Aquat. Ecosyst., 420, 20. 